\title{
Somatic Symptoms and Sleep Disorders: A Literature Review of Their Relationship, Comorbidities and Treatment
}

\author{
Claudiu Gabriel Ionescu ${ }^{1}\left(\mathbb{D}\right.$, Ovidiu Popa-Velea ${ }^{1, *}{ }^{\mathbb{C}}$, Alexandra Ioana Mihăilescu ${ }^{1}\left(\mathbb{D}\right.$, Ana Anca Talaşman ${ }^{2}$ \\ and Ioana Anca Bădărău ${ }^{3}$ \\ 1 Department of Medical Psychology, Faculty of Medicine, University of Medicine and Pharmacy Carol Davila, \\ 050474 Bucharest, Romania; claudiu.ionescu@drd.umfcd.ro (C.G.I.); mihailescu@umfcd.ro (A.I.M.) \\ 2 Department of Psychiatry, Faculty of Medicine, University of Medicine and Pharmacy Carol Davila, \\ 050474 Bucharest, Romania; ana.talasman@umfcd.ro \\ 3 Department of Physiology, Faculty of Medicine, University of Medicine and Pharmacy Carol Davila, \\ 050474 Bucharest, Romania; anca.badarau@umfcd.ro \\ * Correspondence: ovidiu.popa-velea@umfcd.ro
}

Citation: Ionescu, C.G.; Popa-Velea, O.; Mihăilescu, A.I.; Talaşman, A.A.; Bădărău, I.A. Somatic Symptoms and Sleep Disorders: A Literature Review of Their Relationship, Comorbidities and Treatment. Healthcare 2021, 9 , 1128. https://doi.org/10.3390/ healthcare 9091128

Academic Editor: Jitendra Singh

Received: 7 July 2021

Accepted: 27 August 2021

Published: 30 August 2021

Publisher's Note: MDPI stays neutral with regard to jurisdictional claims in published maps and institutional affiliations.

Copyright: (c) 2021 by the authors. Licensee MDPI, Basel, Switzerland. This article is an open access article distributed under the terms and conditions of the Creative Commons Attribution (CC BY) license (https:// creativecommons.org/licenses/by/ $4.0 /)$.
Abstract: This study aimed to investigate the relationship between somatic symptom disorder (SSD) and sleep disorders, following three research questions: (1) How are these disorders correlated? (2) What are the comorbidities reported in these patients? and (3) What are the most effective pharmacological and non-pharmacological treatments for both conditions? PubMed, Scopus, OVID, Medline, and ProQuest databases were searched for relevant articles published between 1957-2020. Search terms included "somatic symptoms disorder", "sleep disorders", "insomnia", "somatoform", "somatization", "therapeutic", "psychotherapy", and alternative, formerly used terms for SSD. Forty papers were finally included in the study. Prevalence of insomnia in SSD patients ranged between $20.4-48 \%$, with this being strongly correlated to somatic symptoms and psychosocial disability. The most relevant comorbidities were generalized anxiety disorder, depression, fatigue, negative mood, substance use, orthorexia, alexithymia, anorexia, weight loss, poor eating habits, and acute stress disorder. Patients receiving antidepressant therapy reported significant improvements in insomnia and somatic symptoms. In terms of non-pharmacological interventions, cognitive-behavioral therapy (CBT) showed improvements in sleep outcomes, while the Specialized Treatment for Severe Bodily Distress Syndromes (STreSS) may represent an additional promising option. Future research could include other medical and psychosocial variables to complete the picture of the relationship between sleep disorders and somatic symptoms.

Keywords: somatoform; insomnia; sleep; somatization; somatic symptoms

\section{Introduction}

In normal individuals, somatic symptoms and sleep disorders are two common conditions that are often connected to acute stress exposure, often in demanding workrelated contexts [1]. If persistent, both symptoms can impact quality of life and may require the use of individual counseling and/or organizational supportive systems dedicated to stress prevention and relief [2,3]. Even using these tools, durable alterations of sleep patterns and somatic functioning are still seen in $14-17 \%$ of individuals screened for these concerns [4-10].

A particular category of somatic patients are those suffering of somatic symptom disorder (SSD). According to DSM-V [11], SSD consists in recurring and multiple physical complaints, such as headaches, dizziness, chest pain, abdominal pain, and limb pain. These symptoms do not need to be medically unexplained and may be the consequence of a medical condition. The diagnosis is based on the degree to which a person's thoughts, feelings, and behavior about their somatic symptoms are disproportionate or excessive. Specifically, one must experience six months of one distressing or disrupting somatic symptom that 
causes disproportionate and persistent thoughts, feelings, and behavior or that takes up extra time and energy. The symptoms must be clinically significant (i.e., they require medical intervention and impair areas of functioning) and not intentionally produced or feigned. Patients with SSD may report sleep disorders (i.e., patient's dissatisfaction regarding the quality, timing, and amount of sleep, with resulting daytime distress and impairment [11]) almost twice as frequently (24-32\%) than the general population [12,13]. Part of the abovementioned symptoms are particularly important in patients complaining of burdening symptoms, such as pain, where, for example, insomnia can be found in $40-80 \%$ of cases $[14,15]$. The potential of creating a veritable vicious circle between the somatic and sleep disorders, with important effects on the patients' quality of life, highlights the need to understand the possible role of sleep disorders in the evolution and exacerbation of symptoms among patients with SSD. This relationship should be also investigated from the perspective of the potential role of additional factors, such as psychiatric comorbidities (depression and anxiety), which may frequently occur in this kind of patient [16,17].

In general, the study of sleep disorders in SSD patients is a challenging objective for at least several reasons:

- Definitions and classifications regarding SSD have been a subject of controversy over the past few years. For example, the new DSM-V definition of SSD [11], although being focused on abnormal and excessive thoughts, feelings, and behaviors associated with the burden of somatic symptoms, puts a lower emphasis on their medical explicability and sourcing [18-20];

- $\quad$ Despite somatic patients often displaying sleep disorders, not all of them fully meet the DSM-V criteria for SSD. This is partially explained by the DSM-V requiring the symptoms to be persistent (more than six months) and to generate a significant disruption of daily life [11];

- A further cause of bias is represented by the discrepancy between subjective and objective overall sleep quality measures [21]. Although subjective sleep measures have certain advantages (they are less expensive, able to be utilized in large populationbased or community-based studies, and very easily standardized), they may overreport sleep duration length among elderly adults or adults in poor health. In contrast, objective measures, despite being more suitable for an adequate evaluation of sleep patterns, are generally costly, invasive, and less tolerated by patients. As a result, $25-50 \%$ of patients seek medical attention for sleep disorders [22], while about 20-30\% of them develop persisting symptoms, and 71\% display a significantly lower quality of life and/or extreme social burden [23,24]; and

- Among SSD patients, a high number of them exhibit conditions, such as depression, anxiety, and fatigue, which themselves are correlated with sleep disorders [25].

As a result of the abovementioned issues, current literature data on the comorbidity of SSD and sleep disorders is still limited. Sleep disorders are not being standardly addressed in the workup of SSD, while, at the same time, they can have consequences for the functionality of the patient and create a vulnerability to further somatic symptoms. In order to clarify the relationship between these two entities, the current literature review aims to answer three questions: (1) How are somatic symptoms in SSD correlated with sleep disorders? (2) What are the most common comorbidities seen in patients with SSD and sleep disorders? and (3) What are the potentially effective pharmacological and non-pharmacological treatment options for both SSD and sleep disorders?

\section{Materials and Methods}

OVID, Medline, PubMed, ProQuest Journals, Web of Science, and Scopus were searched for English language studies on humans published between 1957-2020, assessing somatic symptoms and sleep quality on participants over 18 years old. Papers taken into consideration were peer-reviewed articles, systematic reviews, and meta-analyses corresponding to a level of evidence greater than five in the hierarchy set by the Cen- 
tre for Evidence-Based Medicine [26] and including the terms "somatic symptoms disorder", "sleep disorders", "insomnia", "somatoform", "somatization", "therapeutic", and "psychotherapy" alongside alternative, formerly used terms for SSD ("somatization disorder", "medically unexplained symptoms", "bodily distress syndrome", "multisomatoform disorder", and "non-organic pain").

Exclusion criteria comprised articles centered on (1) obstructive sleep apnea and other similar sleep conditions with possible organic causes, (2) somatic symptoms and complaints caused by chronic organic disorders, (3) pain perception after purposeful sleep restriction, (4) fibromyalgia and related disorders, (5) psychotic disorders and schizophrenia-like disorders, and (6) dementia and related disorders. In addition, when analyzing the third study objective, we limited the search to randomized controlled trials, as we aimed for higher methodological accuracy. The reference lists of retrieved articles were also manually searched for additional information relevant for the study aims.

The search was performed according to the PRISMA extension for scoping reviews and the PRISMA-ScR checklist [27]. The first search yielded 1646 hits, which resulted in 800 articles after removing duplicates. Their titles and abstracts were screened for adequacy, defined as addressing both somatic symptoms/somatoform/somatization symptoms together with insomnia/sleep quality/insufficient sleep disorders. Forty relevant articles were finally included in the review (Figure 1). All team members read the full-texts of all the selected articles and agreed upon their inclusion in the review. No additional articles were added after reviewing the references of the selected papers.

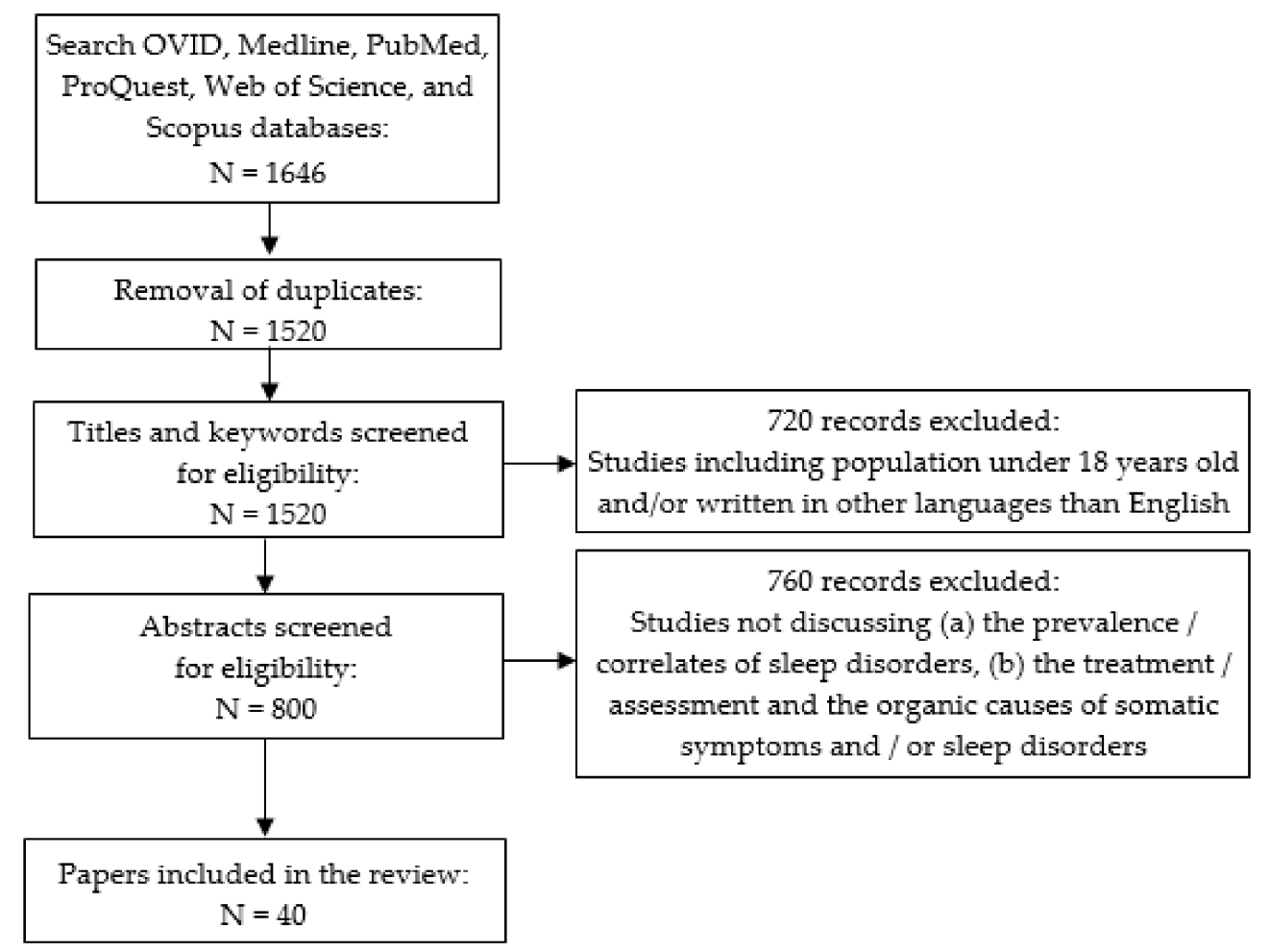

Figure 1. Flow diagram of included articles.

\section{Results}

\subsection{How Are Somatic Symptoms in SSD Correlated to Sleep Disorders?}

The search criteria addressing the prevalence, relationship, and prognosis of somatic symptoms in SSD and sleep disorders yielded 15 articles, with sample sizes ranging from 13 to 28,714 (Table 1). Four studies recruited their participants from a psychiatric unit, six from epidemiological studies, and two comprised students, while the other three included healthy volunteers. Eight studies were cross-sectional, while seven were cohort studies. 
Table 1. Relationship between sleep disorders and somatization.

\begin{tabular}{|c|c|c|c|c|c|}
\hline Study Authors & Country & Study Design & $n$ & Study Aim & Outcomes \\
\hline $\begin{array}{l}\text { Vollrath et al. } \\
\text { (1989) [28] }\end{array}$ & Switzerland & Cohort & 457 & $\begin{array}{l}\text { The association of insomnia with } \\
\text { functional syndromes }\end{array}$ & $\begin{array}{l}\text { Insomnia was associated with } \\
\text { functional somatic complaints }\end{array}$ \\
\hline $\begin{array}{l}\text { Kim et al. } \\
\text { (2001) [29] }\end{array}$ & Japan & Cohort & 303 & $\begin{array}{c}\text { The correlation between insomnia } \\
\text { and somatic and psychological } \\
\text { complaints }\end{array}$ & $\begin{array}{l}\text { The prevalence of insomnia } \\
\text { increased with the number of } \\
\text { somatic complaints }\end{array}$ \\
\hline $\begin{array}{c}\text { Aigner } \\
\text { et al. (2003) [30] }\end{array}$ & Austria & $\begin{array}{l}\text { Cross- } \\
\text { sectional }\end{array}$ & 147 & $\begin{array}{l}\text { Pain intensity in patients with and } \\
\text { without sleep disorders }\end{array}$ & $\begin{array}{l}\text { Sleep disorders were correlated with } \\
\text { higher pain in somatoform pain } \\
\text { disorder patients }\end{array}$ \\
\hline El-Anzi (2006) [31] & Kuwait & $\begin{array}{c}\text { Cross- } \\
\text { sectional }\end{array}$ & 358 & $\begin{array}{l}\text { Results of scales regarding } \\
\text { depression, anxiety, insomnia, and } \\
\text { somatic symptoms }\end{array}$ & $\begin{array}{l}\text { Somatic symptoms were correlated } \\
\text { to insomnia }\end{array}$ \\
\hline $\begin{array}{l}\text { Zhang } \\
\text { et al. (2012) [32] }\end{array}$ & $\begin{array}{l}\text { Hong } \\
\text { Kong }\end{array}$ & Cohort & 256 & $\begin{array}{l}\text { Gender differences in patients } \\
\text { presenting both sleep disorders and } \\
\text { somatization }\end{array}$ & $\begin{array}{l}\text { Insomnia and poor sleep quality was } \\
\text { closely associated with pain and } \\
\text { somatic symptoms }\end{array}$ \\
\hline $\begin{array}{l}\text { Schlarb et al. } \\
\text { (2017) [33] }\end{array}$ & Germany & Cohort & 2443 & $\begin{array}{l}\text { The association between somatic } \\
\text { complaints and sleep disorders }\end{array}$ & $\begin{array}{l}\text { Somatic complaints are positively } \\
\text { associated with subjectively poor } \\
\text { sleep quality }\end{array}$ \\
\hline $\begin{array}{c}\text { Asai } \\
\text { et al. (2006) [34] }\end{array}$ & Japan & Cohort & 28,714 & $\begin{array}{l}\text { The relationship between } \\
\text { somatization and sleep disorders }\end{array}$ & $\begin{array}{l}\text { The prevalence of sleep disorders } \\
\text { increased with the number of } \\
\text { somatic complaints }\end{array}$ \\
\hline $\begin{array}{l}\text { LeBlanc } \\
\text { et al. (2009) [35] }\end{array}$ & Canada & Cohort & 464 & $\begin{array}{l}\text { Factors related to new-onset } \\
\text { insomnia }\end{array}$ & $\begin{array}{l}\text { Higher bodily pain was associated } \\
\text { with new-onset insomnia }\end{array}$ \\
\hline $\begin{array}{l}\text { Zhang et al. } \\
\text { (2012) [36] }\end{array}$ & $\begin{array}{l}\text { Hong } \\
\text { Kong }\end{array}$ & Cohort & 2316 & $\begin{array}{l}\text { The longitudinal course of insomnia } \\
\text { in patients with mental disorders }\end{array}$ & $\begin{array}{l}\text { Baseline insomnia was associated } \\
\text { with chronic pain and poor } \\
\text { mental health }\end{array}$ \\
\hline $\begin{array}{l}\text { Nagane et al. } \\
\text { (2016) [37] }\end{array}$ & Japan & $\begin{array}{l}\text { Cross- } \\
\text { sectional }\end{array}$ & 135 & $\begin{array}{l}\text { Sleep-wake patterns as predictors for } \\
\text { somatic complaints }\end{array}$ & $\begin{array}{l}\text { The sleep-wake pattern may predict } \\
\text { somatic complaints }\end{array}$ \\
\hline $\begin{array}{l}\text { Tan et al. } \\
\text { (1984) [38] }\end{array}$ & USA & $\begin{array}{l}\text { Cross- } \\
\text { sectional }\end{array}$ & 100 & $\begin{array}{l}\text { The association between high } \\
\text { emotional arousal and insomnia in } \\
\text { SSD patients }\end{array}$ & $\begin{array}{l}\text { SSD were much more common as an } \\
\text { additional diagnosis in patients with } \\
\text { primary insomnia }\end{array}$ \\
\hline $\begin{array}{l}\text { Ohaeri and Adeyemi } \\
\text { (1990) [39] }\end{array}$ & Nigeria & $\begin{array}{c}\text { Cross- } \\
\text { sectional }\end{array}$ & 74 & Patterns of somatization symptoms & $\begin{array}{l}\text { Insomnia was the most common } \\
\text { symptom in patients with } \\
\text { somatization }\end{array}$ \\
\hline $\begin{array}{l}\text { Schneider- } \\
\text { Helmert et al. } \\
\text { (2001) [40] }\end{array}$ & $\begin{array}{l}\text { The } \\
\text { Nether- } \\
\text { lands }\end{array}$ & $\begin{array}{l}\text { Cross- } \\
\text { sectional }\end{array}$ & 51 & $\begin{array}{l}\text { The association between insomnia } \\
\text { and chronic non-organic pain }\end{array}$ & $\begin{array}{l}\text { Insomnia is more than a minor } \\
\text { component of chronic } \\
\text { non-organic pain }\end{array}$ \\
\hline Guo et al. (2017) [41] & China & $\begin{array}{c}\text { Cross- } \\
\text { sectional }\end{array}$ & 7602 & $\begin{array}{l}\text { The relationship between depression, } \\
\text { pain, and sleep quality }\end{array}$ & $\begin{array}{l}\text { Perceived pain and poor sleep } \\
\text { quality were correlated with the } \\
\text { number of doctor visits }\end{array}$ \\
\hline $\begin{array}{l}\text { Moldofsky et al. } \\
\quad \text { (1976) [42] }\end{array}$ & Canada & $\begin{array}{l}\text { Cross- } \\
\text { sectional }\end{array}$ & 13 & $\begin{array}{l}\text { The relationship between sleep } \\
\text { disorders and musculoskeletal } \\
\text { symptoms }\end{array}$ & $\begin{array}{c}\text { The emergence of somatic symptoms } \\
\text { is induced by a disorder of } \\
\text { non-REM sleep }\end{array}$ \\
\hline
\end{tabular}

All studies included a majority of female participants, ranging from $51 \%$ to $65 \%$. Most studies included a variety of symptoms, either somatic (somatoform pain, bodily distress, bodily pain, other somatic symptoms) or sleep-related (insomnia, sleep quality, difficulty maintaining sleep, early morning awakening, short sleep duration, and insufficient sleep).

In six studies, insomnia was highly or moderately correlated with the presence of somatic symptoms [28-33]. When a larger number of somatic and psychological symptoms were taken into consideration, the prevalence of symptoms in participants with insomnia was even higher [34]. The new onset of insomnia at the one-year follow-up was associated with a higher level of bodily pain and somatic symptoms, among other psychological variables [35].

The severity of insomnia was correlated with the severity of somatic symptoms [32].

This connection extended beyond severity to the presence of somatic symptoms itself and was confirmed during a follow-up study over a five-year time span, which identified insomnia as a predictor of several specific somatic symptoms and physical disorders [36]. However, this effect is not limited to insomnia, as changes in sleep-wake cycle can themselves be associated to the occurrence of somatic symptoms [37].

Despite this seemingly unilateral cause-effect relationship, other authors suggest the existence of a bidirectional connection between insomnia and somatic complaints [30]. 
More specifically, insomnia could represent a factor in the persistence and aggravation of already-present somatic symptoms as well as in enhancing the psychosocial disability derived from somatic symptoms.

In terms of diagnosis, several studies pointed out that insomnia was more commonly identified than SSD, which is often seen as a secondary diagnosis alongside Axis I psychiatric disorders. From this perspective, a different clinical approach of these conditions and their relationship appears as a critical point to be addressed in future care strategies [38-40].

A genetic predisposition with concomitant heritability of somatic symptoms and sleep disorders has been demonstrated, although the contribution of genetic and environmental factors seems comparable ( $\mathrm{pG}=0.41-0.96$ vs. $\mathrm{pG}=0.27-0.40$ ) [32].

Regarding general functioning, insomnia associated with somatic symptoms was correlated to low overall subjective well-being, poorer academic performance, a higher number of doctor visits, and psychosocial disability in four studies $[32,34,38,41]$ and with the lack of motivation, according to one study performed on academic trainees $(r=-0.18$, $p<0.05)$ [33].

An important approach of the relationship between somatic symptoms and insomnia was highlighted in a study where sleep deprivation was performed and in which authors found a direct connection between musculoskeletal symptoms/tenderness and non-REM sleep deprivation [42]. This study must be mentioned as historically important, as it opened the pathway for developing hybrid treatments in SSD, targeting the shared mechanisms of insomnia and chronic pain.

\subsection{What Are the Most Common Psychiatric Comorbidities Seen in Patients with SSD and Insomnia?}

Table 2 outlines 13 studies addressing common psychiatric and psychological comorbidities seen in patients with somatic symptoms and insomnia. The sample sizes ranged from 52 to 148,938 .

The most relevant comorbidities were generalized anxiety disorder, depression [43], fatigue, negative mood [44-47], substance use disorders (with reports of somatic symptoms and insomnia overlapping withdrawal symptoms) [48], orthorexia nervosa [49], alexithymia [50], anorexia, weight loss, poor eating habits, and acute stress disorder [45,51,52]. An interesting finding was reported by Byers, who established a positive role of cognitive pre-sleep arousal in insomnia patients comorbid with chronic pain as a predictor for insomnia severity $(t=2.77, p<0.01)$. In the same study, pain-catastrophizing did not play a role in insomnia; however, it was independently associated to depression [53].

The reported somatic symptoms varied across studies, from simple somatic complaints to frank SSD and from pain somatoform symptoms to undifferentiated somatoform disorder. Five studies $[44,47,52,54,55]$ were population-based, while the other recruited patients were admitted in hospitals. The identified studies were mainly organized around major psychiatric comorbidities, such as depression and/or anxiety disorders.

\subsection{What Are the Potentially Effective Pharmacological and Non-Pharmacological Treatment Options for Both Somatic Symptoms and Insomnia?}

The selected treatment options for SSD and sleep disorders are reviewed in Tables 3 and 4 . Post-treatment follow-up was on average 12 weeks for pharmacological trials and 9 months for non-pharmacological trials. 
Table 2. Comorbidities in patients with SSD and sleep disorders.

\begin{tabular}{|c|c|c|c|c|c|}
\hline Study Authors & Country & Study Design & $n$ & Study Aim & Outcomes \\
\hline $\begin{array}{l}\text { Hartz et al. } \\
\text { (2013) [43] }\end{array}$ & USA & $\begin{array}{l}\text { Cross- } \\
\text { sectional }\end{array}$ & 148,938 & $\begin{array}{l}\text { The association between somatic } \\
\text { symptoms and sleep disorders }\end{array}$ & $\begin{array}{l}\text { Sleep disorders were positively } \\
\text { correlated with somatic symptoms in } \\
\text { depressive patients }\end{array}$ \\
\hline $\begin{array}{l}\text { Gillespie et al. } \\
\text { (1999) [44] }\end{array}$ & Australia & Cohort & 3468 & $\begin{array}{l}\text { Depression and anxiety symptoms in } \\
\text { patients with somatization }\end{array}$ & $\begin{array}{c}\text { Somatic symptoms were not } \\
\text { genetically or biologically associated } \\
\text { to anxiety/depression }\end{array}$ \\
\hline $\begin{array}{c}\text { Stapleton and } \\
\text { Brunetti (2013) } \\
\text { [45] }\end{array}$ & Australia & $\begin{array}{l}\text { Cross- } \\
\text { sectional }\end{array}$ & 167 & $\begin{array}{l}\text { The association between depression, } \\
\text { somatization, and anxiety and their } \\
\text { effect on eating habits }\end{array}$ & $\begin{array}{l}\text { Higher somatization scores were } \\
\text { positively associated with } \\
\text { depression, anxiety, and poor eating } \\
\text { habits }\end{array}$ \\
\hline $\begin{array}{l}\text { Annagür et al. } \\
\text { (2014) [46] }\end{array}$ & Turkey & $\begin{array}{l}\text { Case- } \\
\text { control }\end{array}$ & 187 & $\begin{array}{l}\text { Self-esteem, depressive mood, and } \\
\text { their impact on somatic symptoms }\end{array}$ & $\begin{array}{l}\text { Depression and anxiety were linked } \\
\text { to chronic pain and sleep disorders }\end{array}$ \\
\hline $\begin{array}{l}\text { Bekhuis et al. } \\
\text { (2016) [47] }\end{array}$ & $\begin{array}{l}\text { The } \\
\text { Netherlands }\end{array}$ & Cohort & 2704 & $\begin{array}{l}\text { The association of somatic symptoms } \\
\text { and anxiety/depression }\end{array}$ & $\begin{array}{c}\text { Depression and anxiety were } \\
\text { associated with somatic complaints } \\
\text { and insomnia }\end{array}$ \\
\hline $\begin{array}{l}\text { Mol et al. } \\
\text { (2005) [48] }\end{array}$ & $\begin{array}{l}\text { The } \\
\text { Netherlands }\end{array}$ & $\begin{array}{l}\text { Cross- } \\
\text { sectional }\end{array}$ & 193 & $\begin{array}{l}\text { The pattern of association between } \\
\text { depression, somatization, and } \\
\text { benzodiazepines craving }\end{array}$ & $\begin{array}{l}\text { Self-reported negative mood and } \\
\text { somatization were positively } \\
\text { associated with craving }\end{array}$ \\
\hline $\begin{array}{l}\text { Barthels et al. } \\
\text { (2021) [49] }\end{array}$ & Germany & $\begin{array}{c}\text { Case- } \\
\text { control }\end{array}$ & 61 & $\begin{array}{l}\text { The association of orthorexia and } \\
\text { depression in SSD patients }\end{array}$ & $\begin{array}{l}\text { Orthorexia levels were elevated in } \\
\text { patients with SSD }\end{array}$ \\
\hline $\begin{array}{l}\text { Lankes et al. } \\
(2020)[50]\end{array}$ & Germany & $\begin{array}{l}\text { Cross- } \\
\text { sectional }\end{array}$ & 160 & $\begin{array}{l}\text { The effect of alexithymia on SSD } \\
\text { patients }\end{array}$ & $\begin{array}{l}\text { Alexithymia mediated by negative } \\
\text { affect was found in patients with } \\
\text { somatoform pain }\end{array}$ \\
\hline $\begin{array}{l}\text { Davidson et al. } \\
\text { (1985) [51] }\end{array}$ & USA & $\begin{array}{l}\text { Cross- } \\
\text { sectional }\end{array}$ & 52 & $\begin{array}{l}\text { The pattern of neurovegetative } \\
\text { symptoms in patients with } \\
\text { depression }\end{array}$ & $\begin{array}{l}\text { Major depression was linked with } \\
\text { insomnia, anorexia, and weight loss } \\
\text { in chronic pain patients }\end{array}$ \\
\hline Yu et al. (2019) [52] & Hong Kong & $\begin{array}{l}\text { Cross- } \\
\text { sectional }\end{array}$ & 998 & $\begin{array}{l}\text { The association of stress, depressive } \\
\text { symptoms, and somatization }\end{array}$ & $\begin{array}{l}\text { Stress was associated with } \\
\text { depressive symptoms and somatic } \\
\text { complaints }\end{array}$ \\
\hline $\begin{array}{l}\text { Byers et al. } \\
\text { (2016) [53] }\end{array}$ & USA & $\begin{array}{l}\text { Cross- } \\
\text { sectional }\end{array}$ & 52 & $\begin{array}{l}\text { The impact of cognitive pre-sleep } \\
\text { arousal, catastrophizing on chronic } \\
\text { pain, and insomnia }\end{array}$ & $\begin{array}{l}\text { Cognitive pre-sleep arousal } \\
\text { predicted insomnia severity in } \\
\text { chronic pain patients }\end{array}$ \\
\hline $\begin{array}{l}\text { Yu et al. } \\
\text { (2011) [54] }\end{array}$ & Hong Kong & Cohort & 1433 & $\begin{array}{l}\text { The pattern of somatic presentation } \\
\text { of depression }\end{array}$ & $\begin{array}{l}\text { People with depression were more } \\
\text { likely to have multiple medically } \\
\text { unexplained symptoms, insomnia, } \\
\text { and fatigue }\end{array}$ \\
\hline $\begin{array}{l}\text { Woud et al. } \\
\text { (2016) [55] }\end{array}$ & $\begin{array}{l}\text { Germany/The } \\
\text { Netherlands }\end{array}$ & Cohort & 1538 & $\begin{array}{l}\text { The impact of catastrophic } \\
\text { misinterpretations on SSD }\end{array}$ & $\begin{array}{l}\text { Catastrophic misinterpretations were } \\
\text { predictive for somatoform-related } \\
\text { problems and new onset SSD }\end{array}$ \\
\hline
\end{tabular}

Table 3. Pharmacological treatments addressing both sleep disorders and somatization.

\begin{tabular}{|c|c|c|c|c|c|}
\hline Study Authors & Country & $n$ & Study Aim & Treatment(s) Duration & Outcomes \\
\hline $\begin{array}{l}\text { Lewis-Hall } \\
\text { et al. } \\
\text { (1997) [56] }\end{array}$ & USA & 854 & $\begin{array}{l}\text { The outcome of MDD and } \\
\text { somatization with Fluoxetine } \\
\text { and TCAs }\end{array}$ & $\begin{array}{l}\text { Fluoxetine vs TCAs, } \\
5 \text { weeks }\end{array}$ & $\begin{array}{l}\text { Significant reductions in } \\
\text { somatization and insomnia for both }\end{array}$ \\
\hline $\begin{array}{l}\text { Saletu-Zyhlarz } \\
\text { et al. } \\
\text { (2000) [57] }\end{array}$ & Austria & 30 & $\begin{array}{c}\text { The effects of Zolpidem on } \\
\text { insomnia and other psychiatric } \\
\text { disorders }\end{array}$ & $\begin{array}{l}\text { Zolpidem vs placebo, } \\
1 \text { week }\end{array}$ & $\begin{array}{l}\text { Improvement in sleep efficiency and } \\
\text { somatic complaints }\end{array}$ \\
\hline $\begin{array}{l}\text { Saletu et al. } \\
\text { (2005) [58] }\end{array}$ & $\begin{array}{l}\text { Austria/ } \\
\text { Bulgaria }\end{array}$ & 11 & $\begin{array}{l}\text { The effects of Trazodone on } \\
\text { sleep disturbances }\end{array}$ & $\begin{array}{l}\text { Trazodone, } \\
1 \text { week }\end{array}$ & $\begin{array}{l}\text { Increased slow-wave sleep and } \\
\text { reduced arousal index }\end{array}$ \\
\hline $\begin{array}{l}\text { Han et al. } \\
\text { (2008) [59] }\end{array}$ & $\begin{array}{l}\text { South } \\
\text { Korea }\end{array}$ & 95 & $\begin{array}{l}\text { The efficacy of } \\
\text { Mirtazapine/Venlafaxine } \\
\text { in SSD }\end{array}$ & $\begin{array}{l}\text { Mirtazapine vs. } \\
\text { Venlafaxine, } \\
12 \text { weeks }\end{array}$ & $\begin{array}{c}\text { Somatization scores decreased from } \\
\text { baseline to endpoint for both } \\
\text { therapies, results in favor of } \\
\text { Mirtazapine }\end{array}$ \\
\hline $\begin{array}{l}\text { Kleinstäuber } \\
\text { et al. } \\
\text { (2014) [60] }\end{array}$ & Germany & 2159 & $\begin{array}{l}\text { The effects of pharmacological } \\
\text { therapies on SSD }\end{array}$ & $\begin{array}{l}\text { SSRI vs. SSRI and AP; } \\
\text { variable, according to } \\
\text { included studies }\end{array}$ & $\begin{array}{l}\text { Low-quality evidence in favor of } \\
\text { combined treatment for reducing } \\
\text { the severity of somatic complaints }\end{array}$ \\
\hline
\end{tabular}

TCA, tricyclic antidepressants; NGA, new-generation antidepressants; SSRI, serotonin selective reuptake inhibitors; AP, antipsychotics. 
Table 4. The effect of non-pharmacological treatment on somatic symptoms and sleep disorders.

\begin{tabular}{|c|c|c|c|c|c|}
\hline Study Authors & Country & $n$ & Study Aim & Compared Interventions & Outcomes \\
\hline $\begin{array}{l}\text { Kleinstäuber } \\
\text { et al. } \\
\text { (2011) [61] }\end{array}$ & Germany & 1781 & $\begin{array}{l}\text { The accuracy of STPP } \\
\text { for somatization and } \\
\text { depression }\end{array}$ & STPP vs. control & $\begin{array}{l}\text { STPP significantly reduced } \\
\text { somatic symptoms and } \\
\text { depression }\end{array}$ \\
\hline $\begin{array}{l}\text { Van Dessel } \\
\text { et al. } \\
\text { (2014) [62] }\end{array}$ & $\begin{array}{l}\text { The Nether- } \\
\text { lands }\end{array}$ & 2658 & $\begin{array}{l}\text { The effectiveness of } \\
\text { CBT on somatization } \\
\text { patients }\end{array}$ & $\begin{array}{c}\text { CBT vs. } \\
\text { usual/enhanced care }\end{array}$ & $\begin{array}{l}\text { CBT reduced somatic } \\
\text { symptoms at 1-year follow-up } \\
\text { but was not more effective } \\
\text { compared with enhanced care }\end{array}$ \\
\hline $\begin{array}{l}\text { Abbas et al. } \\
(2020)[63]\end{array}$ & $\begin{array}{l}\text { United } \\
\text { Kingdom }\end{array}$ & 2004 & $\begin{array}{l}\text { STPP on patients with } \\
\text { somatization }\end{array}$ & STPP vs. minimal treatment & $\begin{array}{c}\text { STPP significantly } \\
\text { outperformed minimal } \\
\text { treatment }\end{array}$ \\
\hline $\begin{array}{l}\text { Jungquist et al. } \\
\text { (2010) [64] }\end{array}$ & USA & 28 & $\begin{array}{l}\text { The efficiency of CBT } \\
\text { for insomnia and } \\
\text { chronic pain }\end{array}$ & CBT vs. control & $\begin{array}{c}\text { CBT patients exhibited } \\
\text { decreases in sleep latency and } \\
\text { increases in efficiency of sleep } \\
\text { but no difference in pain } \\
\text { severity }\end{array}$ \\
\hline $\begin{array}{l}\text { Schröder et al. } \\
\text { (2012) [65] }\end{array}$ & Denmark & 66 & $\begin{array}{l}\text { The efficiency of } \\
\text { STreSS on patients } \\
\text { with somatization }\end{array}$ & STreSS vs. enhanced care & $\begin{array}{l}\text { STreSS group had a greater } \\
\text { improvement of the primary } \\
\text { outcome than enhanced care }\end{array}$ \\
\hline $\begin{array}{l}\text { Tang et al. } \\
\text { (2012) [66] }\end{array}$ & $\begin{array}{l}\text { United } \\
\text { Kingdom }\end{array}$ & 20 & $\begin{array}{l}\text { The hybrid CBT } \\
\text { intervention on sleep } \\
\text { and pain outcomes }\end{array}$ & $\begin{array}{l}\text { CBT PI vs. symptom } \\
\text { monitoring }\end{array}$ & $\begin{array}{c}\text { Hybrid intervention was } \\
\text { associated with greater } \\
\text { improvement in sleep, } \\
\text { although pain intensity did } \\
\text { not change }\end{array}$ \\
\hline $\begin{array}{l}\text { Pigeon et al. } \\
\text { (2012) [67] }\end{array}$ & USA & 21 & $\begin{array}{l}\text { The efficiency of CBT } \\
\text { PI on patients with } \\
\text { co-occurring pain and } \\
\text { insomnia }\end{array}$ & $\begin{array}{l}\text { CBT PI vs. } \\
\text { waiting list }\end{array}$ & $\begin{array}{l}\text { CBT PI produced significant } \\
\text { improvement in sleep and } \\
\text { disability from pain }\end{array}$ \\
\hline $\begin{array}{l}\text { Fjorback et al. } \\
\text { (2013) [68] }\end{array}$ & Denmark & 119 & $\begin{array}{l}\text { The efficiency of } \\
\text { mindfulness on } \\
\text { somatization }\end{array}$ & $\begin{array}{l}\text { Mindfulness therapy vs. } \\
\text { enhanced care }\end{array}$ & $\begin{array}{l}\text { Mindfulness therapy was } \\
\text { comparable with enhanced } \\
\text { care in improvingsomatic } \\
\text { symptoms and insomnia }\end{array}$ \\
\hline
\end{tabular}

CBT, cognitive-behavioral therapy; STreSS, specialized treatment for severe bodily distress syndromes; STPP, short-term psychodynamic psychotherapy.

Table 3 displays pharmacological treatment options and includes four randomized control trials [56-59] and a systematic review [60]. The most common pharmacological treatment studied was antidepressant therapy, with various combinations of antipsychotics or other new-generation antidepressants. Participants receiving antidepressant therapy reported statistically significant improvement in insomnia and somatic symptoms [56-58]. Other authors suggested that a combination of antidepressant and antipsychotic therapy is better than antidepressant alone in the treatment of SSD and insomnia [59]; however, these combinations should consider the balance between efficacy and side effects.

In current practice, many patients are treated with "off-label" medications that are intended for the treatment of other major comorbidities, like anxiety, depression, and other mental health problems. It remains unclear why medications such as antidepressants are also able to reduce the severity of medically unexplained physical symptoms and insomnia.

Literature on non-pharmacological treatments is summarized in Table 4, including three systematic reviews [61-63] and five other trials [64-68]. In these studies, the follow-up period ranged from a few months to one year, with an average number of non-pharmacological therapy sessions of 11 [61]. Cognitive-behavioral therapy was among the most studied non-pharmacological approaches (CBT) for the association of somatic symptoms and sleep disorders, which was investigated in 26 studies. While some authors considered the quality of evidence for a positive CBT effect as being low to moderate [62], other studies report significant differences in the decrease of pain or pain-disability in patients with sleep disorders receiving pain and insomnia-oriented CBT $[64,66,67]$. Based on the benefits of Pain CBT and Insomnia CBT, two studies looked at a hybrid cognitive-based 
therapy for pain and insomnia (CBT PI) [66,67]. Both of them showed improvements in sleep outcomes but no difference in pain outcomes when compared to Insomnia CBT or Pain CBT alone.

Short-term psychodynamic psychotherapy (STPP) was considered in one study to have an important benefit for the evolution of somatic symptoms, especially via the boost of self-efficacy involved in their perception [61,67].

An important observation [65] was that the majority of psychotherapies do not focus enough on comorbid depression and learned helplessness, which are both frequent in SSD and insomnia.

The Specialized Treatment for Severe Bodily Distress Syndromes (STreSS) was found in one study to lead to a better evolution of somatic symptoms than enhanced usual care [65].

Mindfulness therapy was reported in another study to display comparable effects to enhanced treatment in improving quality of life and decreasing somatic symptoms [68].

\section{Discussion}

The primary goal of this review on the relationship between sleep disorders and SSD was to reduce uncertainty in the field by answering three main questions relevant for the clinical understanding and management of patients displaying SSD and sleep disorders.

In terms of the correlations between somatic symptoms in SSD and sleep disorders, our findings indicate that patients displaying both conditions have more substantial complaints and worse overall outcomes. Their overall prognosis is correlated with the gravity of the somatic symptoms and sleep disorders, taken separately. This can have implications for choosing therapeutic strategies, as each condition could follow different patterns of evolution and prognosis, eventually leading to a negative loop complex without an integrated solution for both syndromes. Consequently, careful and critical follow-up of these patients is needed in order to identify the most appropriate integrated treatment solutions that could have a good benefit/cost ratio.

Partial evidence supports the bidirectional relationship between SSD and sleep disorders. A possible explanation could be based on the sleep disorders affecting repair processes (thereby contributing to the development of chronic pain), while somatic symptoms-related discomfort could influence the functioning of dopamine and endogenous opioid signaling pathways (thereby affecting sleep patterns). These bidirectional associations could be equally mediated by proteins, such as BDNF (brain-derived neurotrophic factors) or proinflammatory cytokines (IL-1 $\beta, \mathrm{TNF}-\alpha$ ), which are involved in both pain perception and sleep disorders [69-72]. We should acknowledge, however, that researchers have still a limited understanding of the complex relationship between SSD and sleep. Beside mediation by neurotransmitters (dopamine, serotonin, or endogenous opioids), alternative theories include the proximity of the pain, sleep, and negative affect and expectation neural pathways or the role played by hyper-arousal states and altered central nervous system information processing [73,74].

Concerning the most common comorbidities seen in patients with SSD and sleep disorders, subjects with both these conditions tend to present multiple symptoms that overlap along their evolution. They are more likely to associate anxiety symptoms, anorexia nervosa, orthorexia nervosa, alexithymia, and catastrophic misinterpretations regarding their somatic condition. Among them, pain and anxiety were reported as risk factors for prognosis [55], while comorbid depression was proven to mediate the relationship between the two variables and to be able to influence nociception and overall prognosis [47]. These findings are important for clinical practice, taking into consideration the multitude of additional variables predicting, maintaining, or mediating the comorbidities of SSD and sleep disorders. From this perspective, substantial research is further needed to identify the best option to address these correlations, especially with respect to symptoms such as alexithymia, anxiety, and orthorexia nervosa. Clinically, the overlap of behavioral indicators of anxiety, certain somatic symptoms, and sleep disorders can also represent a difficulty and requires further refinement of current diagnostic guidelines. 
Regarding the potentially effective pharmacological and non-pharmacological treatment options for both somatic symptoms and sleep disorders, we can conclude that, despite several certitudes, there is still room for research, especially about the role of specific pharmacological therapies. Current guidelines are mostly oriented towards targeted-symptoms and comorbidities and less on the overall improvement of SSD in correlation with sleep disorders. Antidepressant therapy was shown to improve somatic symptoms and sleep in several trials in patients with SSD and comorbid depression and insomnia $[56,59,60]$. Still, more research is needed regarding the efficiency of distinct classes of antidepressant medication. In choosing future treatment options, particular attention should be paid to the cognitive-affective effects of psychotropic medication on encoding, attention, and recall processes, as they may bias the assessment of the results by the physicians and by the patients themselves.

In what concerns non-pharmacological interventions, CBT represents the only psychological approach that has been sufficiently examined regarding its efficacy in SSD patients $[75,76]$. Its main targets could be represented by the negative affect, the helplessness, and the negative expectations, which are common among patients affected by SSD and sleep disorders. CBT aims the replacement of dysfunctional beliefs, the building of a sleep hygiene routine, the use of healthier strategies towards illness, and restructuring of dysfunctional, symptom-related cognitions $[61,62,65-67]$. STPP has a longer duration of treatment effect compared with pharmacological options, which are generally less acceptable and have a time-dependent efficiency, but has brought no statistically significant differences compared to CBT regarding different mental health conditions [63].

As a whole, our results supplement previous literature findings $[77,78]$ and draw attention to patients with SSD who are in ongoing suffering and may repeatedly seek medical care throughout their lives. In this category of patients, sleep disorders and particularly insomnia can trigger important cognitive, affective, and behavioral consequences and lead to a significant decrease in their overall functionality.

In terms of practical implications, our research highlights several lessons for practitioners in the fields where SSD cases are frequently encountered (Psychiatry, Family Medicine, and Internal Medicine). Firstly, they should consider sleep disorders and their approach in tight relationship with the evolution of SSD. This will help them offer better care to their patients based on treatments focused on both insomnia and pain-related symptoms and to better assess their prognosis. This relationship should also be presented to the patient when discussing their condition, thereby encouraging a better understanding of the underlying mechanisms and precipitating factors. The presence of both conditions could imply a high stress-related vulnerability, which could represent a reason for additional psychological investigations and counseling. Clinicians and patients could thus consider the inclusion of medication in the treatment plan (such as antidepressants) but also non-pharmacological options, such as CBT.

\subsection{Limitations}

This study has several limitations. It was run as a systematic review, so some relevant articles may have not been included. The differences in the definition of sleep disorders and SSD were only partially considered. Other sources of potential bias are represented by differences between clinician-rated and self-reported measures, various cultural backgrounds concerning sample study sizes, and cultural differences in experiencing, presenting, and coping with somatic symptoms and sleep disorders.

\subsection{Future Research}

Multiple studies reviewed in this article provide evidence that sleep disorders add to the decrease of functionality in patients with SSD. In this particular category of patients, sleep disorders require both prevention and intervention, with favorable effects on quality of life and functionality of patients. The development of adequate treatment and prevention strategies is most effective when based on a comprehensive understanding of the 
underlying causes of co-morbidity. The pathogenesis of sleep disorders in SSD is, however, not yet clear, and further research based on clinical and preclinical studies is needed.

Based on the presented data, investigating the combination of non-pharmacological and pharmacological treatments would be an important direction of research, as both appeared to be more effective than treatment with psychotropic medication alone in anxiety, depression, and in somatization disorders. These effects remained strong and significant up to two years after treatment [79].

Another direction could be represented by the inclusion of new technologies as viable interventions for patients displaying both SSD and sleep disorders. This could include methods such as guided internet-based intervention (iSOMA) for somatic symptoms and related distress and internet-based CBT (CBT-I), both having a wide range of positive effects on the conditions approached in this study and on psychological distress [80].

\section{Conclusions}

Our review aimed to raise awareness for both psychiatric and non-psychiatric practitioners about the importance of prompt detection and treatment of sleep disorders in SSD. Current literature data underpin the importance of assessing both sleep disorders and SSD progression in these patients irrespective of other mental comorbidities. The presence of sleep disorders in SSD can lead to greater severity, longer and disability-generating symptoms, as well as a higher number and severity of associated psychiatric comorbidities. Compared with a targeted treatment model that addresses sleep disorders and SSD separately, a combined treatment model appears to be most effective in terms of costs and prognosis. For comorbid chronic pain and insomnia specifically, a series of pharmacological treatments have had notable results, while CBT remains the best non-pharmacological intervention. Despite the effectiveness of these therapies, future research is critical to assess the value of non-pharmacological and pharmacological treatments in other symptoms of SSD coupled with sleep disorders. Furthermore, describing the pathogenesis and identifying relevant predictive medical and psychosocial variables for the dynamics of SSD and associated sleep disorders are needed to ensure optimal intervention.

Author Contributions: Conceptualization, C.G.I. and O.P.-V.; methodology, O.P.-V. and I.A.B.; software, O.P.-V.; validation, C.G.I., O.P.-V., and I.A.B.; formal analysis, C.G.I. and A.I.M.; investigation, C.G.I., A.I.M., and A.A.T.; resources, C.G.I., A.I.M., and A.A.T.; data curation, A.I.M. and A.A.T.; writing-original draft preparation, C.G.I., A.I.M., and A.A.T.; writing-review and editing, C.G.I., O.P.-V. and I.A.B.; visualization, A.I.M. and A.A.T.; supervision, C.G.I., O.P.-V., and I.A.B.; project administration, O.P.-V. and I.A.B.; funding acquisition, C.G.I. All authors have read and agreed to the published version of the manuscript.

Funding: This research received no external funding.

Institutional Review Board Statement: Not applicable.

Informed Consent Statement: Not applicable.

Conflicts of Interest: The authors declare no conflict of interest.

\section{References}

1. Grossi, G.; Perski, A.; Osika, W.; Savic, I. Stress-related exhaustion disorder-Clinical manifestation of burnout? A review of assessment methods, sleep impairments, cognitive disturbances, and neuro-biological and physiological changes in clinical burnout. Scand. J. Psychol. 2015, 56, 626-636. [CrossRef]

2. Popa-Velea, O.; Diaconescu, L.V.; Gheorghe, I.R.; Olariu, O.; Panaitiu, I.; Cerniţanu, M.; Goma, L.; Nicov, I.; Spinei, L. Factors associated with burnout in medical academia: An exploratory analysis of Romanian and Moldavian physicians. Int. J. Environ. Res. Public Health 2019, 16, 2382. [CrossRef]

3. Popa-Velea, O.; Pamfile, D.; Popp, I. Psychosocial support and burnout at physicians attending advanced care patients: The impact of Balint training. Int. J. Behav. Med. 2014, 21, S95-S96.

4. Faravelli, C.; Salvatori, S.; Galassi, F.; Aiazzi, L.; Drei, C.; Cabras, P. Epidemiology of somatoform disorders: A community survey in Florence. Soc. Psychiatry Psychiatr. Epidemiol. 1997, 32, 24-29. [CrossRef] [PubMed] 
5. Hilderink, P.H.; Collard, R.; Rosmalen, J.G.M.; Oude Voshaar, R.C. Prevalence of somatoform disorders and medically unexplained symptoms in old age populations in comparison with younger age groups: A systematic review. Ageing Res. Rev. 2013, 12, 151-156. [CrossRef]

6. Hiller, W.; Rief, W.; Brähler, E. Somatization in the population: From mild bodily misperceptions to disabling symptoms. Soc. Psychiatry Psychiatr. Epidemiol. 2006, 41, 704-712. [CrossRef]

7. Creed, F.; Barsky, A. A systematic review of the epidemiology of somatisation disorder and hypochondriasis. J. Psychosom. Res. 2004, 56, 391-408. [CrossRef]

8. Zheng, W.; Luo, X.N.; Li, H.Y.; Ke, X.Y.; Dai, Q.; Zhang, C.J.; Ng, C.H.; Ungvari, G.S.; Xiang, Y.T.; Ning, Y.P. Prevalence of insomnia symptoms and their associated factors in patients treated in outpatient clinics of four general hospitals in Guangzhou, China. BMC Psychiatry 2018, 18, 232. [CrossRef] [PubMed]

9. Popa-Velea, O.; Truţescu, C.; Ionescu, E.V.; Almăşan, E.R.; Bobîrnac, G. The usefulness of the Draw-a-Person (DAP) test in the diagnosis and assessment of domestic violence. Rom. J. Leg. Med. 2016, 24, 231-235. [CrossRef]

10. Ancoli-Israel, S.; Roth, T. Characteristics of insomnia in the United States: Results of the 1991 National Sleep Foundation Survey. I. Sleep 1999, 22 (Suppl. 2), S347-S353.

11. American Psychiatric Association. Diagnostic and Statistical Manual of Mental Disorders, 5th ed.; American Psychiatric Association: Arlington, VA, USA, 2013; pp. 309-315.

12. Power, J.D.; Perruccio, A.V.; Badley, E.M. Pain as a mediator of sleep problems in arthritis and other chronic conditions. Arthritis Rheum. 2005, 53, 911-919. [CrossRef] [PubMed]

13. Roizenblatt, S.; Souza, A.L.; Palombini, L.; Godoy, L.M.; Tufik, S.; Bittencourt, L.R. Musculoskeletal pain as a marker of health quality. Findings from the Epidemiological Sleep Study among the adult population of Sao Paulo City. PLoS ONE 2015, 10, e0142726. [CrossRef]

14. Tang, N.K.Y.; Wright, K.J.; Salkovskis, P.M. Prevalence and correlates of clinical insomnia co-occurring with chronic back pain. J. Sleep Res. 2007, 16, 85-95. [CrossRef]

15. Artner, J.; Cakir, B.; Spiekermann, J.A.; Kurz, S.; Leucht, F.; Reichel, H.; Lattig, F. Prevalence of sleep deprivation in patients with chronic neck and back pain: A retrospective evaluation of 1016 patients. J. Pain Res. 2013, 6, 1-6. [CrossRef]

16. de Waal, M.W.; Arnold, I.A.; Eekhof, J.A.; van Hemert, A.M. Somatoform disorders in general practice: Prevalence, functional impairment and comorbidity with anxiety and depressive disorders. Br. J. Psychiatry 2004, 184, 470-476. [CrossRef] [PubMed]

17. Lieb, R.; Meinlschmidt, G.; Araya, R. Epidemiology of the association between somatoform disorders and anxiety and depressive disorders: An update. Psychosom. Med. 2007, 69, 860-863. [CrossRef]

18. Dimsdale, J.E.; Levenson, J. What's next for somatic symptom disorder? Am. J. Psychiatry 2013, 170, 1393-1395. [CrossRef] [PubMed]

19. Löwe, B.; Mundt, C.; Herzog, W.; Brunner, R.; Backenstrass, M.; Kronmüller, K.; Henningsen, P. Validity of current somatoform disorder diagnoses: Perspectives for classification in DSM-V and ICD-11. Psychopathology 2008, 41, 4-9. [CrossRef]

20. Toussaint, A.; Murray, A.M.; Voigt, K.; Herzog, A.; Gierk, B.; Kroenke, K.; Rief, W.; Henningsen, P.; Löwe, B. Development and validation of the Somatic Symptom Disorder-B Criteria Scale (SSD-12). Psychosom. Med. 2016, 78, 5-12. [CrossRef] [PubMed]

21. Moul, D.E.; Hall, M.; Pilkonis, P.A.; Buysse, D.J. Self-report measures of insomnia in adults: Rationales, choices, and needs. Sleep Med. Rev. 2004, 8, 177-198. [CrossRef]

22. Barsky, A.J.; Borus, J.F. Somatization and medicalization in the era of managed care. JAMA 1995, 274, 1931-1934. [CrossRef] [PubMed]

23. Verhaak, P.F.M.; Meijer, S.A.; Visser, A.P.; Wolters, G. Persistent presentation of medically unexplained symptoms in general practice. Fam. Pract. 2006, 23, 414-420. [CrossRef]

24. Jackson, J.L.; Passamonti, M. The outcomes among patients presenting in primary care with a physical symptom at 5 years. J. Gen. Intern. Med. 2005, 20, 1032-1037. [CrossRef]

25. Roth, T. Insomnia: Definition, prevalence, etiology, and consequences. J. Clin. Sleep Med. 2007, 3 (Suppl. 5), S7-S10. [CrossRef]

26. Oxford Centre for Evidence-Based Medicine-Levels of Evidence. Available online: http://www.cebm.net/index.aspx?o=1025 (accessed on 15 March 2020).

27. Tricco, A.C.; Lillie, E.; Zarin, W.; O’Brien, K.K.; Colquhoun, H.; Levac, D.; Moher, D.; Peters, M.D.J.; Horsley, T.; Weeks, L.; et al. Preferred reporting items for systematic reviews and meta-analyses extension for scoping reviews (PRISMA-ScR) checklist. Ann. Intern. Med. 2018, 169, 467-473. [CrossRef] [PubMed]

28. Vollrath, M.; Wicki, W.; Angst, J. The Zürich study. Eur. Arch. Psychiatry Neurol. Sci. 1989, 239, 113-124. [CrossRef]

29. Kim, K.; Uchiyama, M.; Liu, X.; Shibui, K.; Ohida, T.; Ogihara, R.; Okawa, M. Somatic and psychological complaints and their correlates with insomnia in the Japanese general population. Psychosom. Med. 2001, 63, 441-446. [CrossRef]

30. Aigner, M.; Graf, A.; Freidl, M.; Prause, W.; Weiss, M.; Kaup-Eder, B.; Saletu, B.; Bach, M. Sleep disturbances in somatoform pain disorder. Psychopathology 2003, 36, 324-328. [CrossRef] [PubMed]

31. El-Anzi, F.O. Insomnia in relation to depression and somatic symptoms. Psychol. Rep. 2006, 99, 171-175. [CrossRef] [PubMed]

32. Zhang, J.; Lam, S.-P.; Li, S.X.; Tang, N.L.; Yu, M.W.M.; Li, A.M.; Wing, Y.K. Insomnia, sleep quality, pain, and somatic symptoms: Sex differences and shared genetic components. Pain 2012, 153, 666-673. [CrossRef] [PubMed]

33. Schlarb, A.A.; Claßen, M.; Hellmann, S.M.; Vögele, C.; Gulewitsch, M.D. Sleep and somatic complaints in university students. J. Pain Res. 2017, 10, 1189-1199. [CrossRef] 
34. Asai, T.; Kaneita, Y.; Uchiyama, M.; Takemura, S.; Asai, S.; Yokoyama, E.; Miyake, T.; Harano, S.; Suzuki, K.; Ibuka, E.; et al. Epidemiological study of the relationship between sleep disturbances and somatic and psychological complaints among the Japanese general population. Sleep Biol. Rhythm. 2006, 4, 55-62. [CrossRef]

35. LeBlanc, M.; Mérette, C.; Savard, J.; Ivers, H.; Baillargeon, L.; Morin, C.M. Incidence and risk factors of insomnia in a populationbased sample. Sleep 2009, 32, 1027-1037. [CrossRef]

36. Zhang, J.; Lam, S.P.; Li, S.X.; Yu, M.W.; Li, A.M.; Ma, R.C.; Kong, A.P.; Wing, Y.K. Long-term outcomes and predictors of chronic insomnia: A prospective study in Hong Kong Chinese adults. Sleep Med. 2012, 13, 455-462. [CrossRef]

37. Nagane, M.; Suge, R.; Watanabe, S.-I. Time or retiring and sleep quality may be predictors of academic performance and psychosomatic disorder in university students. Biol. Rhythm Res. 2016, 47, 329-337. [CrossRef]

38. Tan, T.L.; Kales, J.D.; Kales, A.; Soldatos, C.R.; Bixler, E.O. Biopsychobehavioral correlates of insomnia. IV: Diagnosis based on DSM-III. Am. J. Psychiatry 1984, 141, 357-362. [CrossRef]

39. Ohaeri, J.U.; Adeyemi, J.D. The pattern of somatization symptoms at the Ibadan Teaching Hospital Psychiatric Clinic. West. Afr. J. Med. 1990, 9, 26-34. [PubMed]

40. Schneider-Helmert, D.; Whitehouse, I.; Kumar, A.; Lijzenga, C. Insomnia and alpha sleep in chronic non-organic pain as compared to primary insomnia. Neuropsychobiology 2001, 43, 54-58. [CrossRef] [PubMed]

41. Guo, J.; Liu, C.; Wang, X.; Qu, Z.; Zhang, W.; Zhang, X. Relationships between depression, pain and sleep quality with doctor visits among community-based adults in north-west China. Public Health 2017, 147, 30-38. [CrossRef]

42. Moldofsky, H.; Scarisbrick, P. Induction of neurasthenic musculoskeletal pain syndrome by selective sleep stage deprivation. Psychosom. Med. 1976, 38, 35-44. [CrossRef]

43. Hartz, A.; Ross, J.J.; Noyes, R.; Williams, P. Somatic symptoms and psychological characteristics associated with insomnia in postmenopausal women. Sleep Med. 2013, 14, 71-78. [CrossRef] [PubMed]

44. Gillespie, N.; Kirk, K.M.; Heath, A.C.; Martin, N.G.; Hickie, I. Somatic distress as a distinct psychological dimension. Soc. Psychiatry Psychiatr. Epidemiol. 1999, 34, 451-458. [CrossRef] [PubMed]

45. Stapleton, P.B.; Brunetti, M. The effects of somatisation, depression, and anxiety on eating habits among university students. Int. J. Heal. Caring 2013, 13, 1-16.

46. Annagür, B.B.; Uguz, F.; Apiliogullari, S.; Kara, İ.; Gunduz, S. Psychiatric disorders and association with quality of sleep and quality of life in patients with chronic pain: A SCID-Based Study. Pain Med. 2014, 15, 772-781. [CrossRef]

47. Bekhuis, E.; Schoevers, R.A.; van Borkulo, C.D.; Rosmalen, J.G.M.; Boschloo, L. The network structure of major depressive disorder, generalized anxiety disorder and somatic symptomatology. Psychol. Med. 2016, 46, 2989-2998. [CrossRef]

48. Mol, A.J.J.; Gorgels, W.J.M.J.; Oude Voshaar, R.C.; Breteler, M.H.; van Balkom, A.J.; van de Lisdonk, E.H.; Kan, C.C.; Zitman, F.G. Associations of benzodiazepine craving with other clinical variables in a population of general practice patients. Compr. Psychiatry 2005, 46, 353-360. [CrossRef]

49. Barthels, F.; Müller, R.; Schüth, T.; Friederich, H.-C.; Pietrowsky, R. Orthorexic eating behavior in patients with somatoform disorders. Eat Weight Disorders. 2021, 26, 135-143. [CrossRef]

50. Lankes, F.; Schiekofer, S.; Eichhammer, P.; Busch, V. The effect of alexithymia and depressive feelings on pain perception in somatoform pain disorder. J. Psychosom. Res. 2020, 133, 110101. [CrossRef]

51. Davidson, J.; Krishnan, R.; France, R.; Pelton, S. Neurovegetative symptoms in chronic pain and depression. J. Affect. Disord. 1985, 9, 213-218. [CrossRef]

52. Yu, N.X.; Chan, J.S.M.; Ji, X.; Wan, A.H.Y.; Ng, S.M.; Yuen, L.P.; Chan, C.L.W.; Chan, C.H.Y. Stress and psychosomatic symptoms in Chinese adults with sleep complaints: Mediation effect of self-compassion. Psychol. Health Med. 2019, 24, 241-252. [CrossRef]

53. Byers, H.D.; Lichstein, K.L.; Thorn, B.E. Cognitive processes in comorbid poor sleep and chronic pain. J. Behav. Med. 2016, 39, 233-240. [CrossRef] [PubMed]

54. Yu, D.S.F.; Lee, D.T.F. Do medically unexplained somatic symptoms predict depression in older Chinese? Int. J. Geriatr. Psychiatry 2011, 27, 119-126. [CrossRef]

55. Woud, M.L.; Zhang, X.C.; Becker, E.S.; Zlomuzica, A.; Margraf, J. Catastrophizing misinterpretations predict somatoform-related symptoms and new onsets of somatoform disorders. J. Psychosom. Res. 2016, 81, 31-37. [CrossRef] [PubMed]

56. Lewis-Hall, F.C.; Wilson, M.G.; Tepner, R.G.; Koke, S.C. Fluoxetine vs. tricyclic antidepressants in women with major depressive disorder. J. Women's Health 1997, 6, 337-343. [CrossRef]

57. Saletu-Zyhlarz, G.; Anderer, P.; Brandstätter, N.; Dantendorfer, K.; Gruber, G.; Mandl, M.; Ritter, K.; Zoghlami, A.; Saletu, B Placebo-controlled sleep laboratory studies on the acute effects of Zolpidem on objective and subjective sleep and awakening quality in nonorganic insomnia related to neurotic and stress-related disorder. Neuropsychobiology 2000, 41, 139-148. [CrossRef] [PubMed]

58. Saletu, B.; Prause, W.; Anderer, P.; Mandl, M.; Aigner, M.; Mikova, O.; Saletu-Zyhlarz, G.M. Insomnia in somatoform pain disorder: Sleep laboratory studies on differences to controls and acute effects of Trazodone, evaluated by the Somnolyzer $24 \times 7$ and the Siesta Database. Neuropsychobiology 2005, 51, 148-163. [CrossRef] [PubMed]

59. Han, C.; Pae, C.-U.; Lee, B.-H.; Ko, Y.-H.; Masand, P.S.; Patkar, A.A.; Joe, S.-H.; Jung, I.-K. Venlafaxine versus Mirtazapine in the treatment of undifferentiated somatoform disorder: A 12-week prospective, open-label, randomized, parallel-group trial. Clin. Drug. Investig. 2008, 28, 251-261. [CrossRef] [PubMed] 
60. Kleinstäuber, M.; Witthöft, M.; Steffanowski, A.; van Marwijk, H.; Hiller, W.; Lambert, M.J. Pharmacological interventions for somatoform disorders in adults. Cochrane Database Syst. 2014, 11, CD010628. [CrossRef]

61. Kleinstäuber, M.; Witthöft, M.; Hiller, W. Efficacy of short-term psychotherapy for multiple medically unexplained physical symptoms: A meta-analysis. Clin. Psychol Rev. 2011, 31, 146-160. [CrossRef]

62. Van Dessel, N.; den Boeft, M.; van der Wouden, J.C.; Kleinstäuber, M.; Leone, S.S.; Terluin, B.; Numans, M.E.; van der Horst, H.E.; van Marwijk, H. Non-pharmacological interventions for somatoform disorders and medically unexplained physical symptoms (MUPS) in adults. Cochrane Database Syst. Rev. 2014, 11, CD011142. [CrossRef]

63. Abbass, A.; Town, J.; Holmes, H.; Luyten, P.; Cooper, A.; Russell, L.; Lumley, M.A.; Schubiner, H.; Allinson, J.; Bernier, D.; et al. Short-term psychodynamic psychotherapy for functional somatic disorders: A meta-analysis of randomized controlled trials. Psychother. Psychosom. 2020, 89, 363-370. [CrossRef]

64. Jungquist, C.R.; O'Brien, C.; Matteson-Rusby, S.; Smith, M.T.; Pigeon, W.R.; Xia, Y.; Lu, N.; Perlis, M.L. The efficacy of cognitivebehavioral therapy for insomnia in patients with chronic pain. Sleep Med. 2010, 11, 302-309. [CrossRef]

65. Schröder, A.; Rehfeld, E.; Ørnbøl, E.; Sharpe, M.; Licht, R.W.; Fink, P. Cognitive-behavioural group treatment for a range of functional somatic syndromes: Randomised trial. Br. J. Psychiatry 2012, 200, 499-507. [CrossRef]

66. Tang, N.K.Y.; Goodchild, C.E.; Salkovskis, P.M. Hybrid cognitive-behaviour therapy for individuals with insomnia and chronic pain: A pilot randomised controlled trial. Behav. Res. Ther. 2012, 50, 814-821. [CrossRef]

67. Pigeon, W.R.; Moynihan, J.; Matteson-Rusby, S.; Jungquist, C.R.; Xia, Y.; Tu, X.; Perlis, M.L. Comparative effectiveness of CBT interventions for co-morbid chronic pain \& insomnia: A pilot study. Behav. Res. Ther. 2012, 50, 685-689. [CrossRef] [PubMed]

68. Fjorback, L.O.; Arendt, M.; Ornbøl, E.; Walach, H.; Rehfeld, E.; Schröder, A.; Fink, P. Mindfulness therapy for somatization disorder and functional somatic syndromes-Randomized trial with one-year follow-up. J. Psychosom. Res. 2013, 74, 31-40. [CrossRef]

69. Sikandar, S.; Minett, M.S.; Millet, Q.; Santana-Varela, S.; Lau, J.; Wood, J.N.; Zhao, J. Brain-derived neurotrophic factor derived from sensory neurons plays a critical role in chronic pain. Brain 2018, 141, 1028-1039. [CrossRef]

70. Sochal, M.; Małecka-Panas, E.; Gabryelska, A.; Fichna, J.; Talar-Wojnarowska, R.; Szmyd, B.; Białasiewicz, P. Brain-derived neurotrophic factor is elevated in the blood serum of Crohn's disease patients, but is not influenced by anti-TNF- $\alpha$ treatment-A pilot study. Neurogastroenterol. Motil. 2020, 33, e13978. [CrossRef] [PubMed]

71. Xue, J.; Li, H.; Xu, Z.; Ma, D.; Guo, R.; Yang, K.; Wang, Y. Paradoxical sleep deprivation aggravates and prolongs incisioninduced pain hypersensitivity via BDNF signaling-mediated descending facilitation in rats. Neurochem. Res. 2018, 43, $2353-2361$. [CrossRef] [PubMed]

72. Boakye, P.A.; Olechowski, C.; Rashiq, S.; Verrier, M.J.; Kerr, B.; Witmans, M.; Baker, G.; Joyce, A.; Dick, B.D. A critical review of neurobiological factors involved in the interactions between chronic pain, depression, and sleep disruption. Clin. J. Pain. 2016, 32, 327-336. [CrossRef] [PubMed]

73. Nijs, J.; Mairesse, O.; Neu, D.; Leysen, L.; Danneels, L.; Cagnie, B.; Meeus, M.; Moens, M.; Ickmans, K.; Goubert, D. Sleep disturbances in chronic pain: Neurobiology, assessment, and treatment in physical therapist practice. Phys. Ther. 2018, 98, 325-335. [CrossRef] [PubMed]

74. Baglioni, C.; Nanovska, S.; Regen, W.; Spiegelhalder, K.; Feige, B.; Nissen, C.; Riemann, D. Sleep and mental disorders: A meta-analysis of polysomnographic research. Psychol. Bull. 2016, 142, 969-990. [CrossRef] [PubMed]

75. Brasure, M.; Fuchs, E.; MacDonald, R.; Nelson, V.A.; Koffel, E.; Olson, C.M.; Khawaja, I.S.; Diem, S.; Carlyle, M.; Wilt, T.J.; et al. Psychological and behavioral interventions for managing insomnia disorder: An evidence report for a clinical practice guideline by the American College of Physicians. Ann. Intern. Med. 2016, 165, 113-124. [CrossRef] [PubMed]

76. Kleinstäuber, M.; Rief, W. Cognitive-behavioral therapy for somatoform disorders and pain. In The Science of Cognitive Behavioral Therapy; Hoffman, S., Asmundson, G., Eds.; Academic Press: London, UK, 2017; pp. 405-427.

77. Barsky, A.J.; Orav, E.J.; Bates, D.W. Somatization increases medical utilization and costs independent of psychiatric and medical comorbidity. Arch. Gen. Psychiatry 2005, 62, 903-910. [CrossRef] [PubMed]

78. Lehmann, M.; Pohontsch, N.J.; Zimmermann, T.; Scherer, M.; Löwe, B. Diagnostic and treatment barriers to persistent somatic symptoms in primary care-Representative survey with physicians. BMC Fam. Pract. 2021, 22, 60. [CrossRef] [PubMed]

79. Cuijpers, P.; Sijbrandij, M.; Koole, S.L.; Andersson, G.; Beekman, A.T.; Reynolds, C.F., 3rd. Adding psychotherapy to antidepressant medication in depression and anxiety disorders: A meta-analysis. World Psychiatry 2014, 13, 56-67. [CrossRef]

80. McCombie, A.; Gearry, R.; Andrews, J.; Mikocka-Walus, A.; Mulder, R. Computerised cognitive behavioural therapy for psychological distress in patients with physical illnesses: A systematic review. J. Clin. Psychol. Med. Settings 2015, 22, 20-44. [CrossRef] 